\title{
VOLUME CHANGES OF CAST IRONS DURING CASTING
}

\author{
By E. J. Ash ${ }^{1}$ and C. M. Saeger, jr.
}

\section{ABSTRACT}

The volume changes occurring in eight types of cast irons during cooling from the liquid state to room temperature are given in this paper. The irons varied in composition from gray iron to white iron.

The coefficient of volume shrinkage in the liquid state for the irons over the range of temperature studied was 0.011 per cent per ${ }^{\circ} \mathrm{C}$. The volume change during solidification varied from an expansion of 1.65 per cent in a gray iron to a contraction of 5.85 per cent in a low-carbon low-silicon type of iron. The linear contraction of the sand-cast bars varied inversely with the silicon and carbon content and also with the cross-sectional area. The lowest linear shrinkage value measured was 0.67 per cent ( $1 \frac{1}{2}$ inch square bar) and the highest was 2.08 per cent (three-fourths inch square bar).

In both heating and cooling curves and in the sand-cast contraction bars, a pronounced effect was observed at about $1,070^{\circ} \mathrm{C}$. possibly indicative of some transformation. An expansion was observed at this temperature during the freezing of all melts of cast iron. This expansion, however, was not due to decomposition of cementite alone, for white iron bars having no free graphite present showed this same phenomenon. This expansion may have been caused by the separation of dissolved gases during solidification as has been pointed out by previous investigators.

\section{CONTENTS}

I. Introduction

II. Materials

III. Apparatus and procedure. 602

IV. Results

1. Specific volume-temperature curves 606

(a) Liquid.... 606

(b) Solid

2. Solidification range

V. Summary

VI. Acknowledgments

\section{INTRODUCTION}

The changes taking place in the linear dimensions of cast iron during cooling from the freezing range to room temperature have been the subject of many investigations. Few studies, however, have been made to determine the volume changes during cooling in the liquid state and during subsequent solidification. This latter information is of fundamental importance to foundrymen in the design and production of sound castings. Its application to the determination of the size and position of gates and risers is essential for the production of castings free from shrink holes and porosity. That soundness of the cast metal is essential in the production of high strength cast irons has been emphasized by Piwowarsky ${ }^{2}$ and many others.

In 1929, the Bureau of Standards, cooperating with the American Foundrymen's Association, undertook the development of a method

1 Research associate representing the American Foundrymen's Association.

2 E. Piwowarsky, Production of High Test Cast Iron, Trans. Am. Fdymen's Assoc., vol. 34, p. 914, 1926. 
for determining the volume changes occurring in cast irons during cooling from some temperature in the liquid state to room temperature.

At the time this work was initiated there were available reports on the determination of the specific volume of liquid cast iron by Benedicks and coworkers, ${ }^{3}$ Desch and Smith, ${ }^{4}$ and Honda and Endo. ${ }^{5}$ Only. Honda and Endo gave values for the volume change during solidification.

Recently, three additional papers dealing with the specific volume of liquid cast irons have been published. Both Benedicks ${ }^{6}$ and Honda, ${ }^{7}$ with their coworkers, have extended their results over a wide range of irons. Widawski and Sauerwald ${ }^{8}$ determined the specific volume of a series of molten cast irons, making measurements up to $1,600^{\circ} \mathrm{C}$. Again, only Honda and his collaborators gave values for the volume change during solidification.

A preliminary report covering the early stages of the work at the Bureau of Standards on the volume changes of cast irons was published in $1930 .^{9}$ A detailed account of the method finally developed for determining the volume changes occurring during the casting of metals and alloys has recently appeared in the Bureau of Standards Journal of Research. ${ }^{10}$ The present paper gives the specific volumetemperature relations of a number of cast irons of varying composition on cooling from some temperature in the liquid state to room temperature.

\section{MATERIALS}

Pig iron from three sources was used in the preparation of the castiron melts. Pig iron B, a soft gray iron, was taken from stock at the Bureau of Standards; pig iron C, an iron of exceptionally uniform composition, all cast from a single ladle, was supplied through the courtesy of the Republic Iron \& Steel Co., Birmingham, Ala.; pig iron $D$, a white iron, was made available through the kindness of H. A. Schwartz, of the National Malleable and Steel Castings Co., Cleveland, Ohio. The chemical composition of these pig irons is given in Table 2. Additions of commercial open-hearth ingot iron were made to the furnace charges when it was necessary to dilute the carbon, silicon, and other constituents of the above irons.

\section{APPARATUS AND PROCEDURE}

The apparatus and methods used for determining the specific volume-temperature relations of metals have been described in detail in previous publications. ${ }^{11}$ The specific volume-temperature curves

C. Benedicks, D. W. Berlin, and G. Phragmen, A Method for the Determination of the Specific Gravity of Liquid Iron and Other Metals of High Melting Point, J. Iron \& Steel Inst., Carnegie Schol. Mem., vol. $13, \mathrm{p}, 129,1924$.

C. H. Desch and B. S. Smith, Interim Report on the Density of Molten Steel, J. Iron \& Steel lnst., vol. 119, p. $538,1929$.

K. Honda and H. Endo, On the Volume Change in Cast Iron during Solidification, Sci. Rpts., Tohoku Imp. Univ., vol. 16, p. 19, 1927.

6 C. Benedicks, N. Ericsson, and G. Ericson, Bestimmung des Spezifischen Volumes von Eisen, Nickel und Eisenlegierungen im Geschmolzenen Zustand, Archiv für das Eisenhüttenwesen, vol. 3, p. 473, 1930.

${ }^{7} \mathrm{~K}$. Honda, T. Kase, and Y. Matuyama, On the Change of Volume of Cast Iron during Solidification, Sci. Repts., Tohoku lmp. Univ., vol, 18, p. 699, 1929.

8 F. Widawski and F. Sauerwalk, Über die Direckte Auftriebsmethode und die Dichte Schmelzflüssiger Metalle, Insbesondere von Eisenlegierungen bei Temperaturen bis $1,600^{\circ} \mathrm{C}$., Zeitschrift für Anorganische und Allgemeine Chemie, vol. 192, p. 145, 1930 .

C. M. Saeger, jr., and E. J. Ash, Methods for Determining the Volume Changes Undergone by Metals and Alloys during Casting, Trans. Am. Foundreymen's Assoc., vol, 38, p. 107, 1930.

${ }^{10}$ C. M. Saeger, jr., and E. J. Ash, A Method for Determining the Volume Changes Occurring in Metals during Casting, B. S. Jour. Research, vol. 8, p. 37, 1932.

1 Seo footnotes 9 and 10 ; 
of liquid cast iron were constructed from data obtained by application of the crucible immersion method. In this method a graphite crucible of known volume is filled with liquid metal at a known temperature. The mass of this sample of metal is the same in the liquid phase as in the solid phase at room temperature. The specific volume of the liquid, therefore, can readily be calculated from the known volume of the crucible at the elevated temperature ${ }^{12}$ and the weight of the solid metal sample. Data on the contraction of the solid metal, obtained by direct observations of the change in length with change in temperature of a sand-cast bar of metal permitted calculation of the specific volume-temperature relation of the solid metal. The difference between the specific volume of the liquid metal and of the solid metal at the temperatures corresponding to the liquidus and the solidus, respectively, represents the volume change during solidification. The liquidus and solidus temperatures for each composition were determined by thermal analysis.

The observations on each heat of cast iron were made as follows:

The charge of iron was melted in a high frequency induction furnace and heated to a maximum temperature of $1,500^{\circ} \mathrm{C}$. for gray iron and $1,600^{\circ} \mathrm{C}$. for white iron. Temperatures were measured by means of a platinum-rhodium thermocouple. When the melt had reached the desired maximum temperature, the power input was reduced sufficiently to permit cooling of the melt, but at a retarded rate, and also to continue a slow stirring action of the bath. The first liquid sample was then taken. Sufficient metal was then transferred to a preheated crucible for casting the solid contraction bars and a small ingot for subsequent determination of the freezing range. Additional liquid samples were taken as the metal cooled in the furnace.

After the samples of liquid metal had cooled to room temperature, the ingots were removed from the crucibles and weighed and the specific volume of the liquid metal was calculated for each sampling temperature. The specific volume-temperature curve of the liquid metal was constructed from these data.

In order to study the effect of cross-sectional area on the volume changes of cast iron two sizes of bars, one $3 / 4$-inch square and the other 1/1/2-inch square, both 12 inches long, were poured from each melt.

The temperature range of solidification was determined by thermal analyses of the small ingot cast for this purpose.

\section{RESULTS}

The shrinkage characteristics were determined for 14 melts of cast iron, representing eight different compositions. The material making up each charge is given in Table 1 . The results of chemical analyses of each of the 14 melts and of the 3 pig irons used in making up the charges are given in Table 2. A summary of the shrinkage data obtained is given in Table 3.

12 The calculation of the volume of the crucible at the elevated temperature depends upon the coefficient of thermal expansion of graphite. The value of this coefficient used in this report was obtained by extra. polation of experimental data from $600^{\circ} \mathrm{C}$. to the temperatures of molten cast iron. Recently, however, this coefficient up to $1,000^{\circ} \mathrm{C}$. has been determined at this bureau. The use of these later data considerably shortens the necessary extrapolation for obtaining the thermal expansion of graphite at the higher temperatures. Specific volumes calculated on the basis of the recent data confirm the validity of the earlier calculations. 
TABLE 1.-Materials constituting charges

\begin{tabular}{|c|c|c|c|c|c|c|}
\hline \multirow{2}{*}{ Melt No. } & \multicolumn{3}{|c|}{ Pig iron } & \multicolumn{2}{|c|}{ Open-hearth iron } & \multirow{2}{*}{ Other additions } \\
\hline & Lot & Weight & $\begin{array}{l}\text { Propor- } \\
\text { tion of } \\
\text { charge }\end{array}$ & Weight & $\begin{array}{l}\text { Propor- } \\
\text { tion of } \\
\text { charge }\end{array}$ & \\
\hline $\begin{array}{l}\text { I } \\
\text { II } \\
\text { III.-. } \\
\text { IV } \\
\text { V.-. }\end{array}$ & $\begin{array}{l}\mathbf{B} \\
\mathbf{B} \\
\mathbf{B} \\
\mathbf{B} \\
\mathbf{B}\end{array}$ & $\begin{array}{r}\text { Pounds } \\
97 \\
105 \\
120 \\
96 \\
72\end{array}$ & $\begin{array}{r}\text { Per cent } \\
100 \\
100 \\
80 \\
80 \\
60\end{array}$ & $\begin{array}{r}\text { Pounds } \\
30 \\
24 \\
48\end{array}$ & $\begin{array}{r}\text { Per cent } \\
20 \\
20 \\
40\end{array}$ & 1 \\
\hline $\begin{array}{l}\text { VI } \\
\text { VII } \\
\text { VIII- } \\
\text { IX } \\
\text { X.... }\end{array}$ & $\begin{array}{l}\mathrm{B} \\
\mathrm{B} \\
\mathrm{C} \\
\mathrm{C} \\
\mathrm{D}\end{array}$ & $\begin{array}{r}78 \\
125 \\
125 \\
125 \\
115\end{array}$ & $\begin{array}{r}60 \\
100 \\
100 \\
100 \\
100\end{array}$ & 52 & 40 & - \\
\hline $\begin{array}{l}\text { XI } \\
\text { XII } \\
\text { XIII }\end{array}$ & $\begin{array}{l}D \\
D \\
C\end{array}$ & $\begin{array}{l}140 \\
140 \\
130\end{array}$ & $\begin{array}{r}100 \\
100 \\
90\end{array}$ & 13 & 10 & $\begin{array}{l}1.4 \text { pounds } \mathrm{FeSi} ;{ }^{1} 0.5 \text { pound } \mathrm{FeMn} .{ }^{2} \\
2.0 \text { pounds } \mathrm{FeSi} ; 0.2 \text { pound } \mathrm{FeMn} ; 0.8\end{array}$ \\
\hline XIV & $\mathrm{C}$ & 127 & 80 & 32 & 20 & $\begin{array}{l}0.75 \text { pound FeSi; } 0.1 \text { pound FeMn; } 0.4 \\
\text { pound } \mathrm{FeP} \text {. }\end{array}$ \\
\hline
\end{tabular}

$1 \mathrm{FeSi}$, ferro silicon containing 50 per cent silicon.

2 FeMn, ferro manganese containing 80 per cent manganese.

$\mathrm{FeP}$, ferro phosphorus containing 25 per cent phosphorus.

TABLE 2.-Composition of cast-iron melts ${ }^{1}$

\begin{tabular}{|c|c|c|c|c|c|c|c|c|}
\hline \multirow{2}{*}{ Melt No. } & \multirow{2}{*}{ Si } & \multirow{2}{*}{$\mathrm{Mn}$} & \multirow{2}{*}{$\mathrm{P}$} & \multirow{2}{*}{$\mathbf{S}$} & \multicolumn{2}{|c|}{ 3/4-inch square bar } & \multicolumn{2}{|c|}{ 132-inch square bar } \\
\hline & & & & & $\begin{array}{c}\text { Total } \\
\text { carbon }\end{array}$ & $\begin{array}{c}\text { Graphitic } \\
\text { carbon }\end{array}$ & $\begin{array}{c}\text { Total } \\
\text { carbon }\end{array}$ & $\begin{array}{l}\text { Graphitic } \\
\text { carbon }\end{array}$ \\
\hline $\begin{array}{l}\text { I } \\
\text { II } \\
\text { III } \\
\text { IV } \\
\text { VI }\end{array}$ & $\begin{array}{r}\text { Per cent } \\
2.08 \\
2.11 \\
1.68 \\
1.69 \\
1.24\end{array}$ & $\begin{array}{r}\text { Per cent } \\
0.50 \\
.50 \\
.44 \\
.48 \\
.35\end{array}$ & $\begin{array}{r}\text { Per cent } \\
0.44 \\
.46 \\
.35 \\
.35 \\
.27\end{array}$ & $\begin{array}{r}\text { Per cent } \\
0.05 \\
.05 \\
.04 \\
.04 \\
.04\end{array}$ & $\begin{array}{r}\text { Per cent } \\
3.63 \\
2.71 \\
3.08 \\
3.10 \\
2.29\end{array}$ & $\begin{array}{r}\text { Per cent } \\
2.99 \\
2.96 \\
2.23 \\
2.27 \\
.42\end{array}$ & $\begin{array}{r}\text { Per cent } \\
3.63 \\
3.71 \\
3.08 \\
3.10 \\
2.18\end{array}$ & $\begin{array}{r}\text { Per cent } \\
2.97 \\
2.99 \\
2.18 \\
2.31 \\
.56\end{array}$ \\
\hline $\begin{array}{l}\text { VII - } \\
\text { VIII. } \\
\text { IX.-- } \\
\text { X...- }\end{array}$ & $\begin{array}{r}2.10 \\
2.87 \\
2.86 \\
.84\end{array}$ & $\begin{array}{l}.54 \\
.59 \\
.58 \\
.24\end{array}$ & $\begin{array}{l}.46 \\
.68 \\
.67 \\
.15\end{array}$ & $\begin{array}{l}.05 \\
.03 \\
.03 \\
.06\end{array}$ & $\begin{array}{l}3.76 \\
3.63 \\
3.60 \\
2.00\end{array}$ & $\begin{array}{r}3.35 \\
3.42 \\
3.40 \\
: 00\end{array}$ & $\begin{array}{l}3.67 \\
3.69 \\
3.39 \\
2.08\end{array}$ & $\begin{array}{r}3.26 \\
3.53 \\
3.20 \\
.00\end{array}$ \\
\hline $\begin{array}{l}\text { XI } \\
\text { XII } \\
\text { XIII } \\
\text { XIV }\end{array}$ & $\begin{array}{r}.85 \\
1.50 \\
2.87 \\
2.88\end{array}$ & $\begin{array}{l}.25 \\
.27 \\
.52 \\
.44\end{array}$ & $\begin{array}{l}.14 \\
.14 \\
.59 \\
.66\end{array}$ & $\begin{array}{l}.06 \\
.06 \\
.03 \\
.03\end{array}$ & $\begin{array}{l}1.96 \\
1.97 \\
3.27 \\
2.89\end{array}$ & $\begin{array}{r}.00 \\
.00 \\
2.90 \\
2.65\end{array}$ & $\begin{array}{l}1.98 \\
1.87 \\
3.27 \\
2.90\end{array}$ & $\begin{array}{r}.00 \\
.01 \\
2.88 \\
2.68\end{array}$ \\
\hline Pig iron & $\mathrm{Si}$ & $\mathrm{Mn}$ & $\mathbf{P}$ & $\mathrm{S}$ & $\begin{array}{c}\text { Total } \\
\text { carbon }\end{array}$ & $\begin{array}{c}\text { Graphitic } \\
\text { carbon }\end{array}$ & Combin & carbon \\
\hline $\begin{array}{l}\text { B } \\
\text { C. } \\
\text { D. }\end{array}$ & $\begin{array}{l}2.31 \\
2.90 \\
1.00\end{array}$ & $\begin{array}{l}0.67 \\
.56 \\
.29\end{array}$ & $\begin{array}{r}0.46 \\
.67 \\
.15\end{array}$ & $\begin{array}{l}0.045 \\
.02 \\
.06\end{array}$ & $\begin{array}{l}3.81 \\
3.68 \\
2.07\end{array}$ & 3.15 & & 0.66 \\
\hline
\end{tabular}

${ }^{1}$ Analyses made by R. H. Elders, American Cast Iron Pipe Co., Birmingham, Ala. 


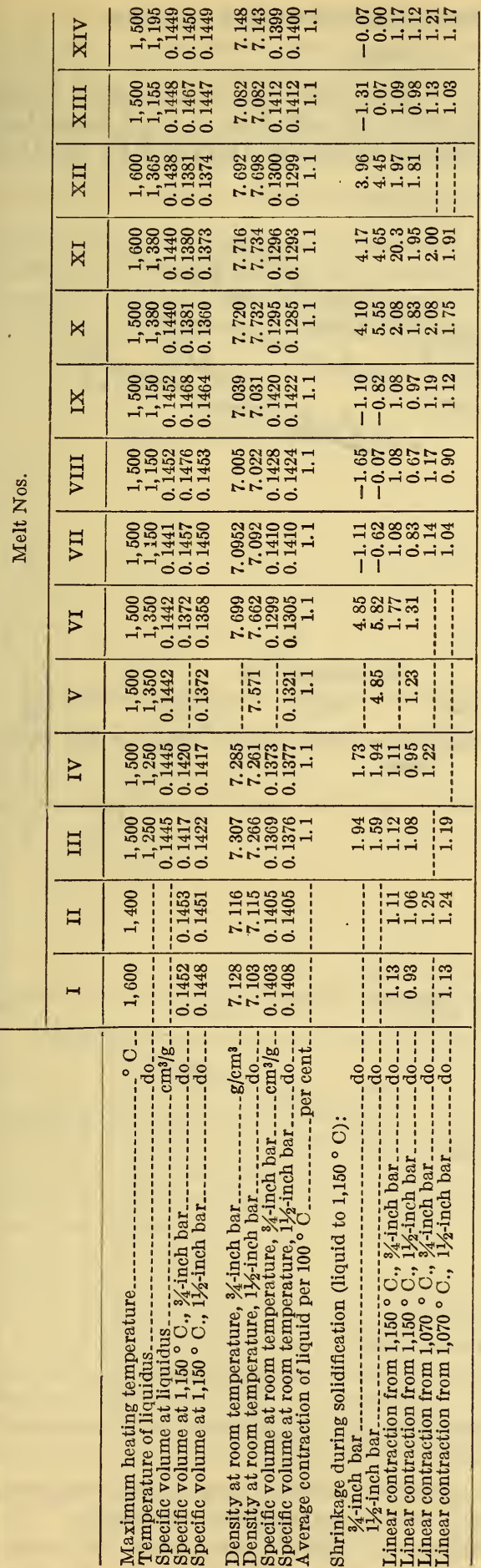




\section{SPECIFIC VOLUME-TEMPERATURE CURVES}

\section{(a) LIQUID}

Figure 1 shows the relation between specific volume and temperature of the liquid metal for 12 melts of cast iron. Cast irons having relatively high carbon and silicon contents (melts VII, VIII, IX,

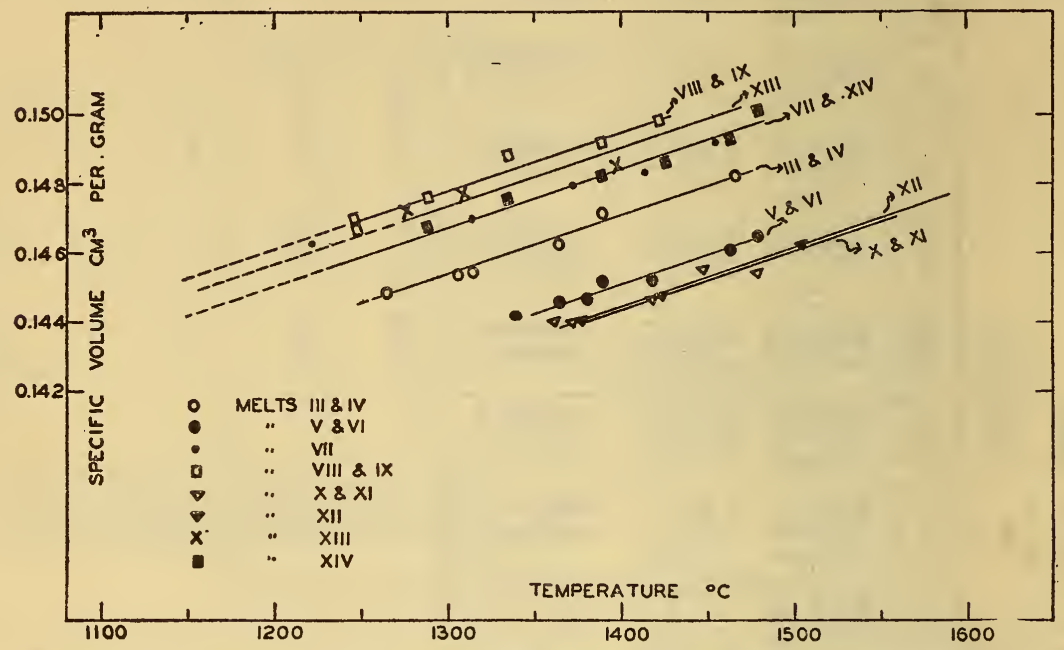

FIgURE 1.-Specific volume-temperature curves of cast irons in the liquid state

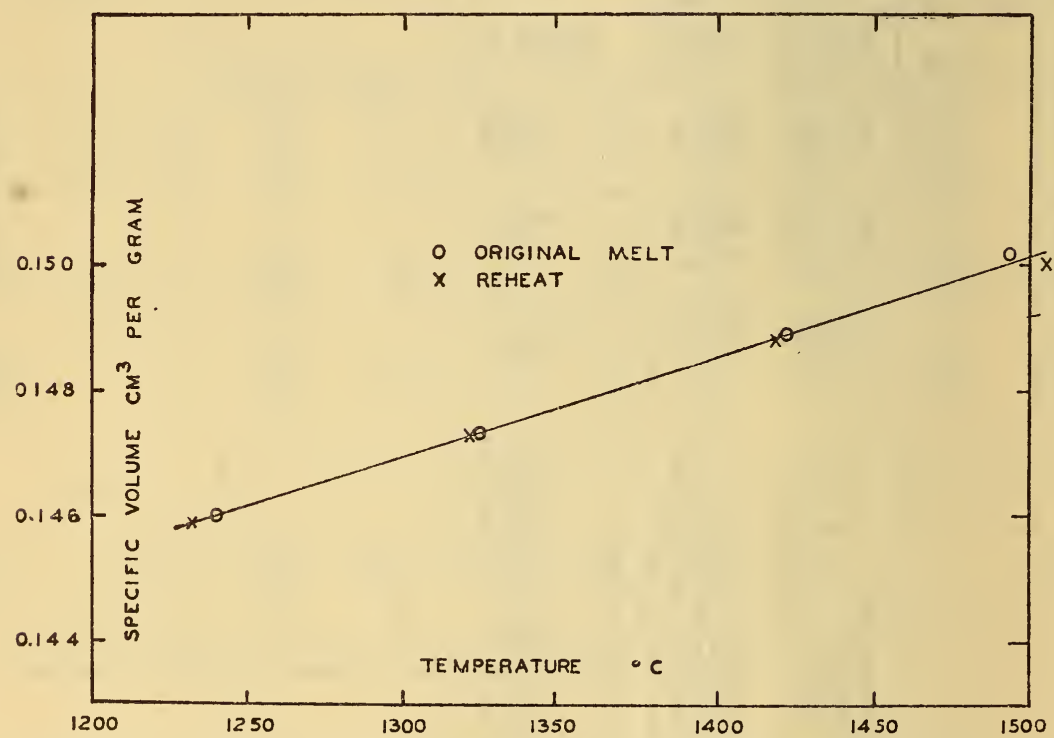

FIgURe 2.-Specific volume-temperature curve of a liquid cast iron after repeated heating and cooling

XIII, and XIV) have greater specific volumes at a given temperature than the cast irons with lower carbon and silicon contents.

Repeated heating and cooling of liquid cast iron indicated no measurable change in the specific volume of the metal. The results 
of a study of this nature are shown in Figure 2. This metal was heated to a maximum temperature in the furnace, poured into a crucible and four liquid samples were taken as the metal cooled. The remaining metal in the crucible was returned to the furnace, reheated to a maximum temperature, again poured into the crucible and four additional liquid samples were obtained as the metal cooled.

\section{(b) SOLID}

The linear contraction-temperature curve of each composition of cast iron in the solid state was obtained by plotting observed changes in length with change in temperature of the cast bars referred to previously. Figure 3 shows a contraction curve for a typical gray

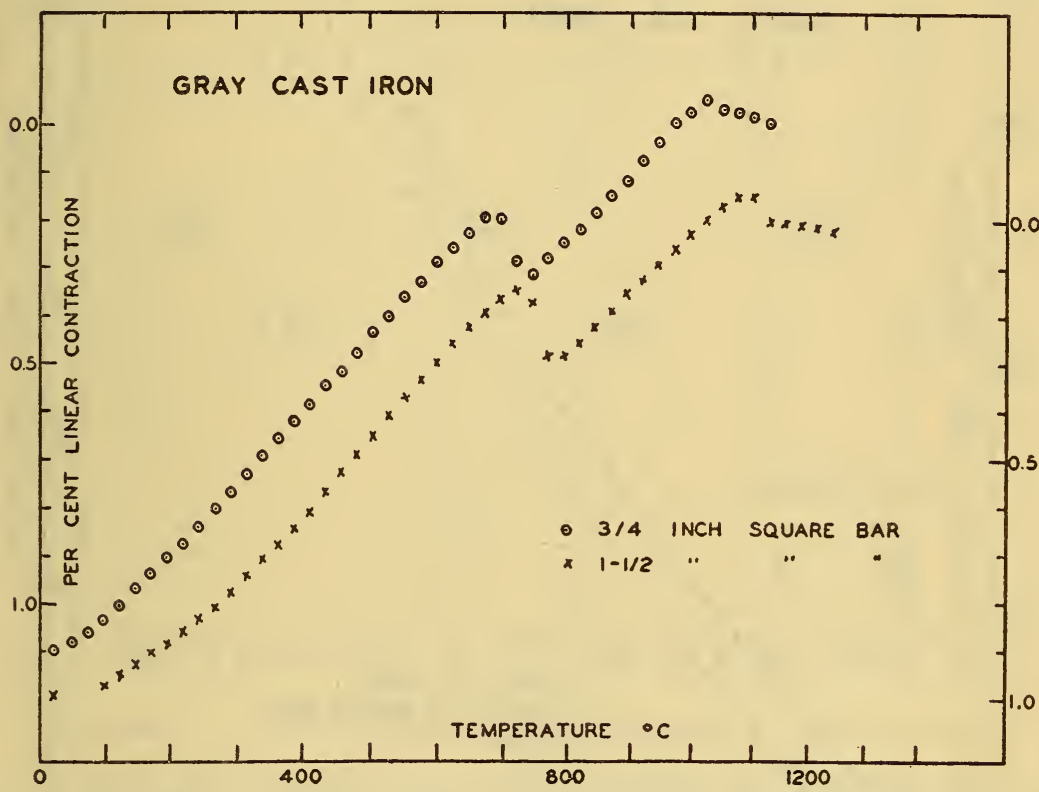

FIGURE 3.-Linear contraction-temperature curve of a gray cast iron

cast iron. In general, all gray cast irons undergo an expansion during or immediately after solidification. The initial expansion indicated by the bar begins at a temperature above $1,130^{\circ} \mathrm{C}$., and reaches a maximum at approximately $1,070^{\circ} \mathrm{C}$. This expansion is also characteristic of white cast iron (fig. 4) and hence, should not be attributed to the decomposition of the cementite because no primary graphite is formed in white iron.

A comparison between the linear shrinkage values from $1,150^{\circ}$ and $1,070^{\circ} \mathrm{C}$., respectively, to room temperature is given in Table 3 .

As the specific volume (or density) of cast iron at room temperature varies with composition and with rate of cooling, the density was determined on each bar. Specimens, one-half inch thick, cut from the free end of the contraction bar were considered to be representative of the metal in that bar. This experimental value for the density of the metal of a given contraction bar at room temperature, together with the observed changes in linear dimensions, of the bar during cooling from the freezing range, permitted the calculation of the 
specific volume of the solid metal throughout the range from the temperature of complete solidification to room temperature.

The expansion phenomenon associated with freezing of cast irons has been observed by a number of investigators. Bardenheuer and Ebbefeld ${ }^{13}$ have attributed this expansion to the release of gases during the transition from fluid to the solid state. This view is in

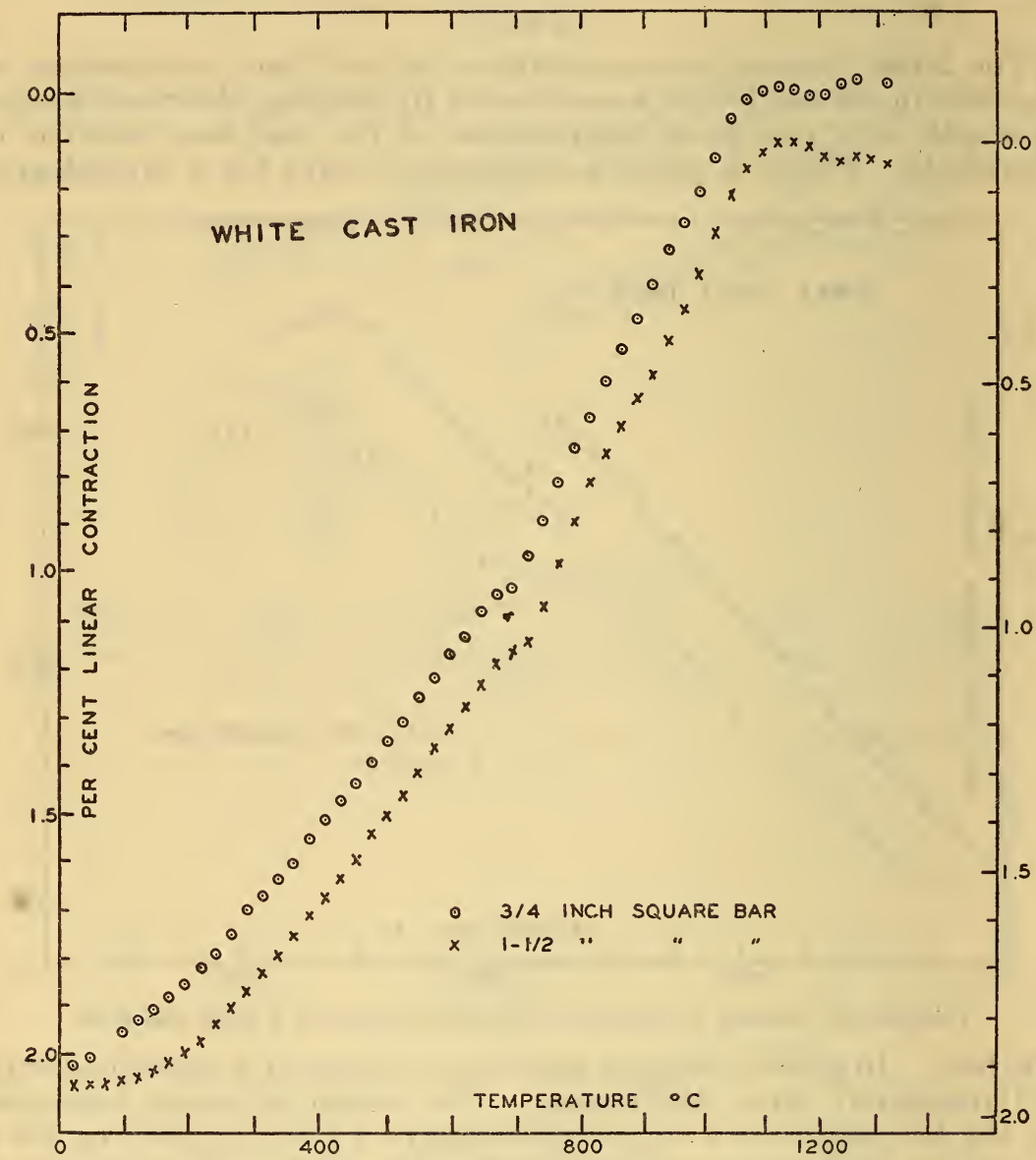

FIGURE 4.-Linear contraction-temperature curve of a white cast iron

agreement with Boehm, ${ }^{14}$ who observed a similar phenomenon for copper-tin alloys.

Piwowarsky ${ }^{15}$ reported a relation between the amount of gas released during solidification and the temperature to which the cast iron had been superheated. He reported the amount of gas given off by a series of cast-iron melts as varying from 1.12 to 2.74 cubic inches per pound of metal. The gas liberated was composed of $\mathrm{CO}, \mathrm{CO}_{2}, \mathrm{H}_{2}$, $\mathrm{N}_{2}$, and $\mathrm{CH}_{4}$. He concluded that this observed expansion at the end of the freezing range was detrimental to the metal inasmuch as it decreased its density.

${ }_{18}$ P. Bardenheuer and C. Ebbefeld, Beitrag zur Analyse des Schwindungsvorganges von weissem und grauem Gusseisen, Stahl u. Eisen, vol. 45, pp. 825 and 1022, 1925.

$14 \mathrm{~F}$. Boehm, Ửber die Schwindung von Legierungen. Dissertation, Technischen Hochschule zu Breslau, 1930 .

16 See footnote 2 p. 601. 


\section{SOLIDIFICATION RANGE}

For the present investigation, because the evaluation of the volume change during solidification depended on the specific volume change between the liquidus and solidus, the extent of the freezing range was determined for each cast iron studied. Typical inverse rate heating and cooling curves for a gray cast iron are shown in Figure 5. There was a break in the time-temperature curve on cooling at about $1,147^{\circ}$ C. which was taken as an indication of the liquidus. On heating, the break in the time-temperature curve was consistently found at about $1,070^{\circ} \mathrm{C}$., the temperature of the solidus.

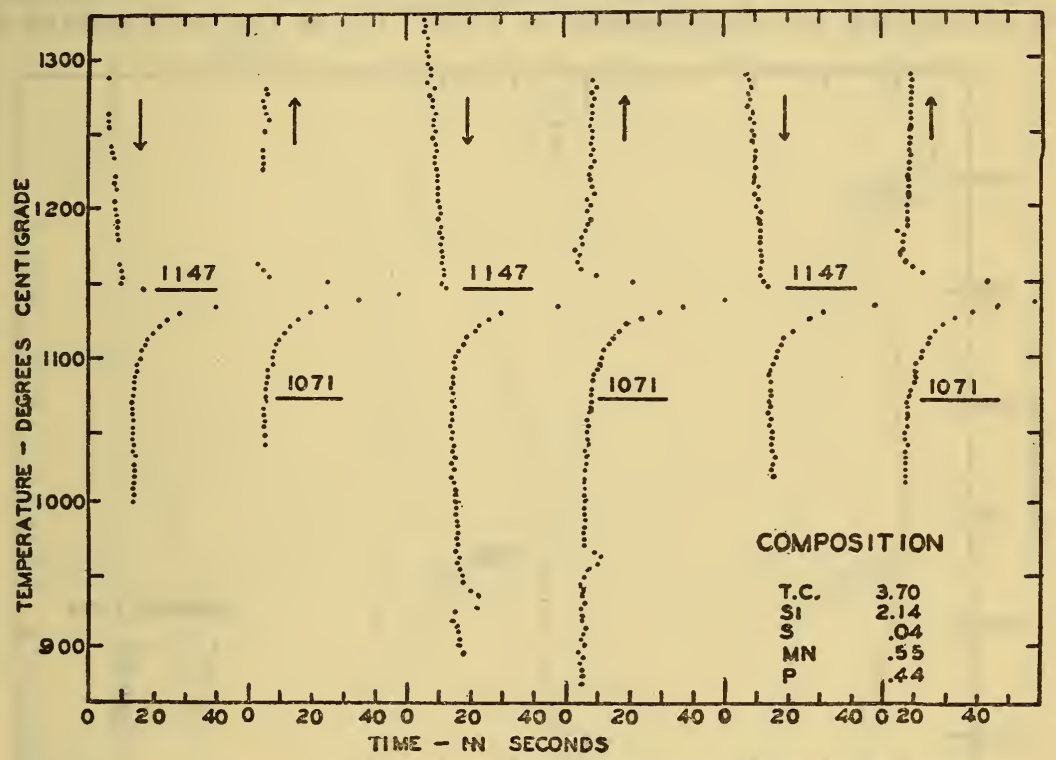

FIGURE 5.-Inverse rate heating and cooling curves of a gray cast iron

A heating and a cooling curve for a white cast iron are given in Figure 6. The liquidus is indicated at $1,380^{\circ} \mathrm{C}$. and the solidus at $1,063^{\circ} \mathrm{C}$.

The occurrence of an apparent solidus at about $1,070^{\circ} \mathrm{C}$. was typical of every cast-iron composition studied. Thermal analyses of specimens of different sizes also indicated this thermal change at approximately $1,070^{\circ} \mathrm{C}$. both on heating and cooling.

This deviation of the cooling curve at about $1,070^{\circ} \mathrm{C}$, appears to be more pronounced in those cast irons containing higher amounts of combined carbon. Thus, in Figure 7, the cooling curve of melt No. VI shows a very distinct halt at approximately this temperature. This is also observed in white cast iron. (See fig. 6.)

The temperature of the occurrence of the maximum expansion of the solid contraction bars coincides with the observed temperature of the apparent solidus for these irons. Because of the complex nature of cast iron, this temperature may represent the change of state of a low melting material (eutectic) formed from the various constituents in the material. The change of structure occurring at $1,070^{\circ} \mathrm{C}$. is not very great because the amount of heat evolved or 
absorbed at this temperature appears to be small. If this expansion phenomenon is due to the separation of occluded gases, the material could not possibly be completely solid until after the maximum expansion had taken place.

Hanson states 16 "that portion (of the iron-carbon diagram) down to and including the eutectic represents an iron-graphite system, but at some temperature below the eutectic line the alloys undergo transformations according to the system iron-cementite." In the diagrams referred to in his statement, the Acm line was not connected with the eutectic horizontal.

The data of the present investigation are considered insufficient for identifying the temperature of $1,070^{\circ} \mathrm{C}$., as the true solidus of

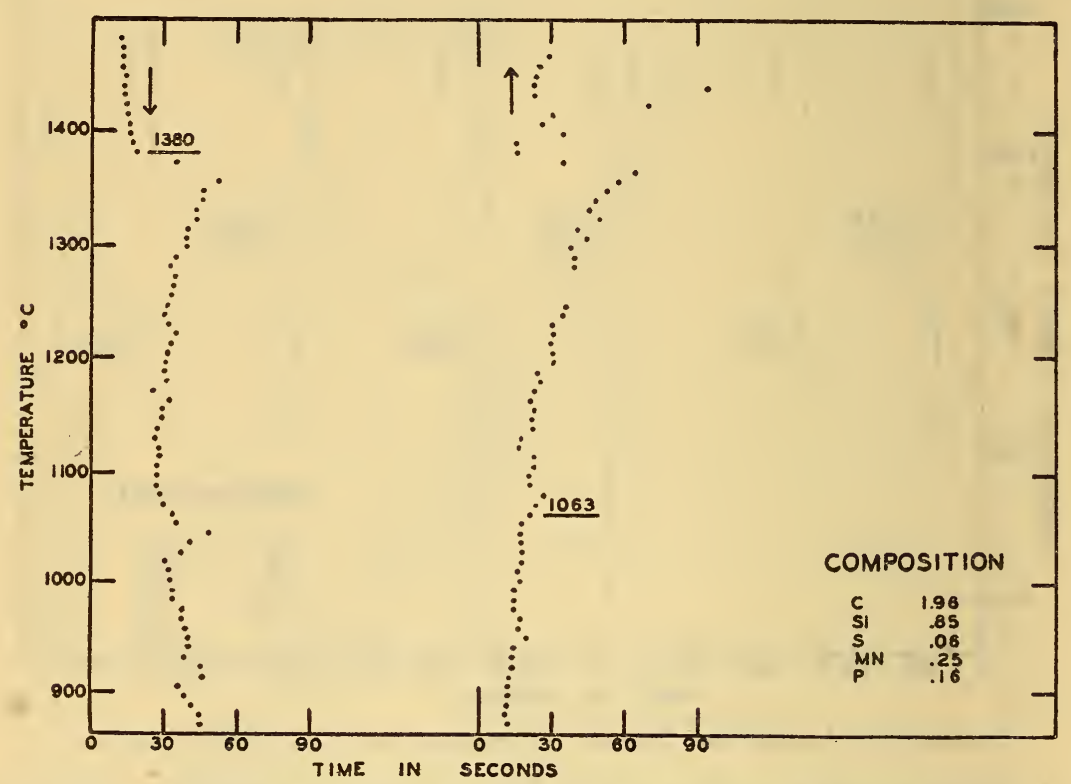

FIGURE 6.-Inverse rate heating and cooling curves of white cast iron

these cast irons. The solidus of cast iron is usually considered to occur between $1,130^{\circ}$ and $1,150^{\circ} \mathrm{C}$., depending upon the composition. Temperature-contraction data of the present investigation indicated that at $1,150^{\circ} \mathrm{C}$. the bars had not, in general, moved appreciably. However, at $1,130^{\circ} \mathrm{C}$., the temperature at which the next observation was made, the free ends of the bars were in motion. Since it was desired to select the solidus at or just above the temperature representing initial movement in the solid bar, the temperature, $1,150^{\circ} \mathrm{C}$., was chosen as the solidus point for all irons.

The specific volume-temperature relations for a cast iron from some temperature in the liquid state to room temperature can be plotted on a single curve. Such curves for three cast irons are shown in Figure 8. These melts (see Table 1) were made from the same lot of pig iron, but two contained different proportions of open-hearth iron. Melt VII was all pig iron B; melt IV was 80 per cent pig iron $B$ and 20 per cent open-hearth iron; melt VI was composed of 60 per

${ }^{16} \mathrm{D}$. Hanson, The Constitution of Silicon-Carbon-Iron Alloys and a New Theory of the Cast Irons, J. Iron \& Steel Inst., vol. 114, p. 129, 1927. 
cent pig iron $\mathrm{B}$ and 40 per cent open-hearth iron. The effect of decreasing amounts of carbon, silicon, and other constituents on the shrinkage characteristics of cast iron is shown in this figure.

The complete shrinkage data for a typical white cast iron (melt XI) are represented in Figure 9.

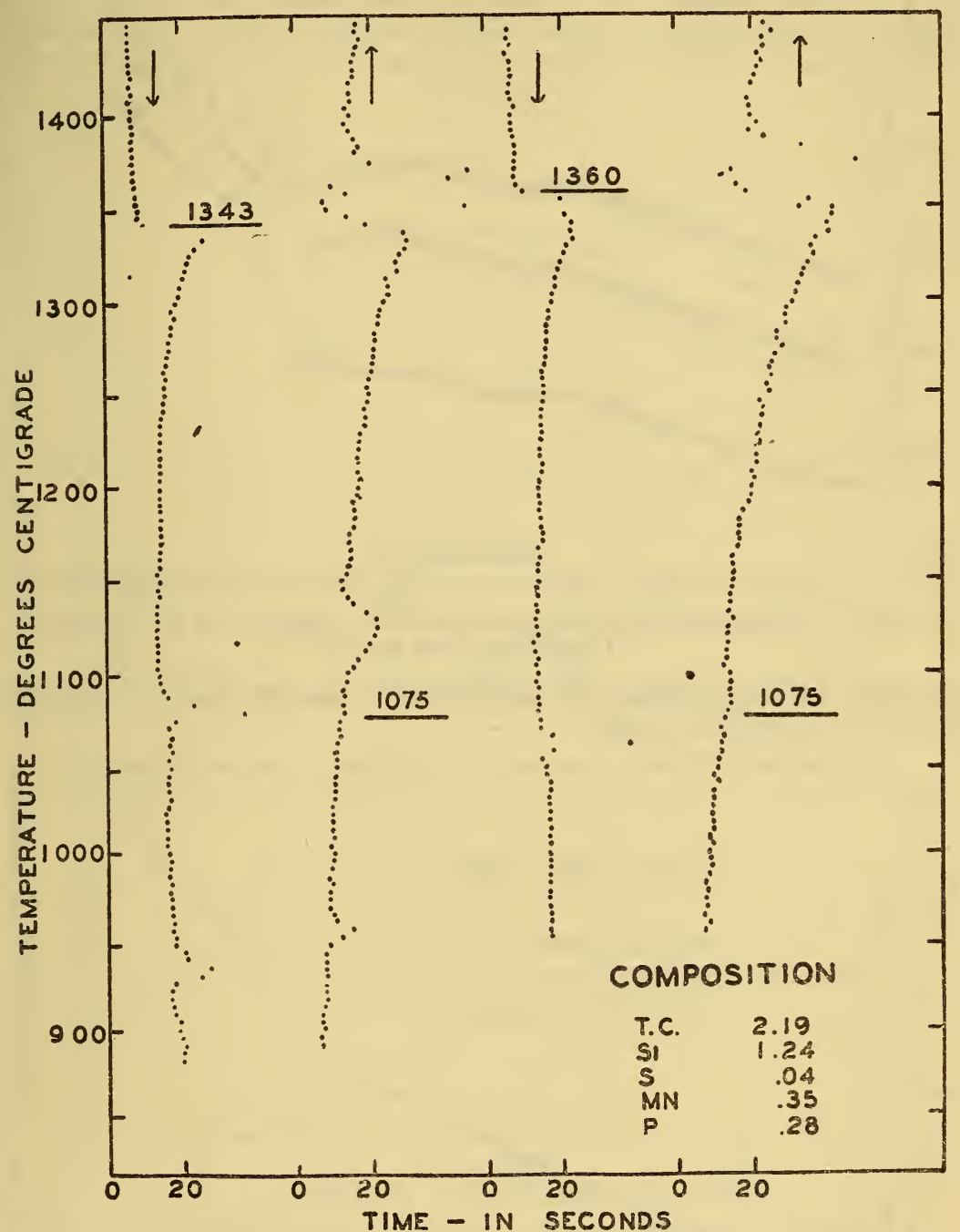

FIGURE 7.-Inverse rate heating and cooling curves of a cast iron diluted with 40 per cent commercial open-hearth ingot iron

In Figure 10, the volume change during solidification of the cast irons studied in this investigation is plotted against the amount of graphitic carbon contained in the solid contraction bars. For purposes of comparison, there are plotted in the same manner the values 
obtained by Honda and his coworkers ${ }^{17}$ on cast irons differing widely in composition from those used in this investigation. The values obtained by Honda, by means of the thermobalance, indicate volume

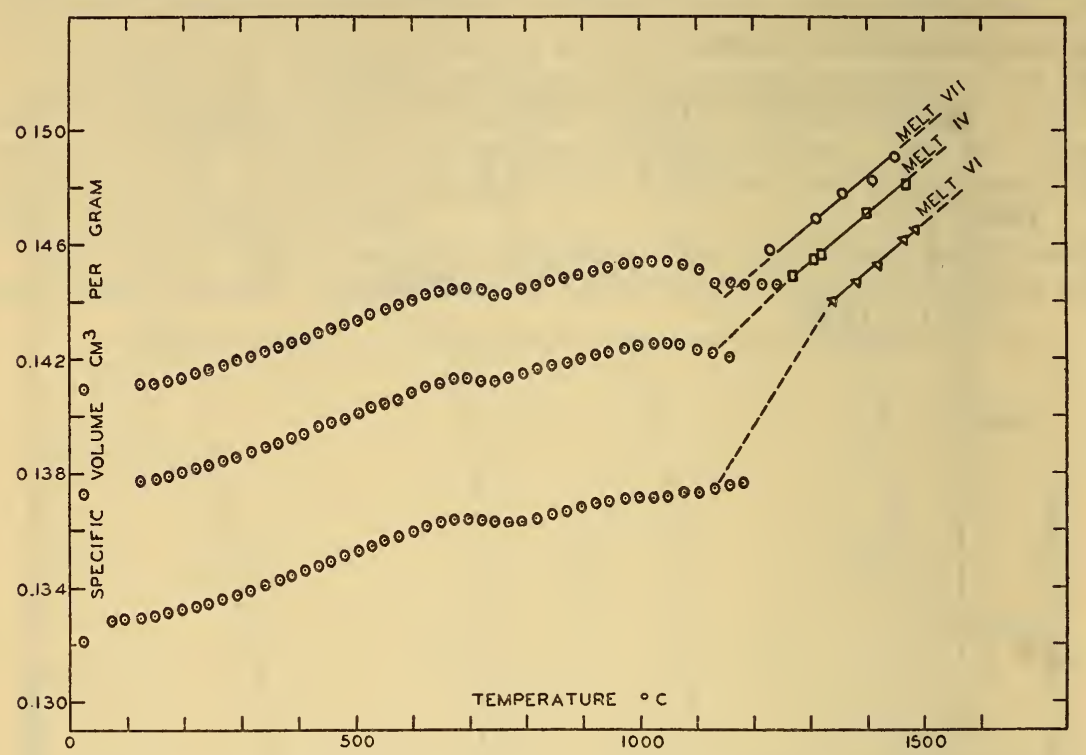

Figure 8.-Complete specific volume-temperature relations for three compositions of gray cast iron

decreases during solidification appreciably smaller than those determined in the present study.

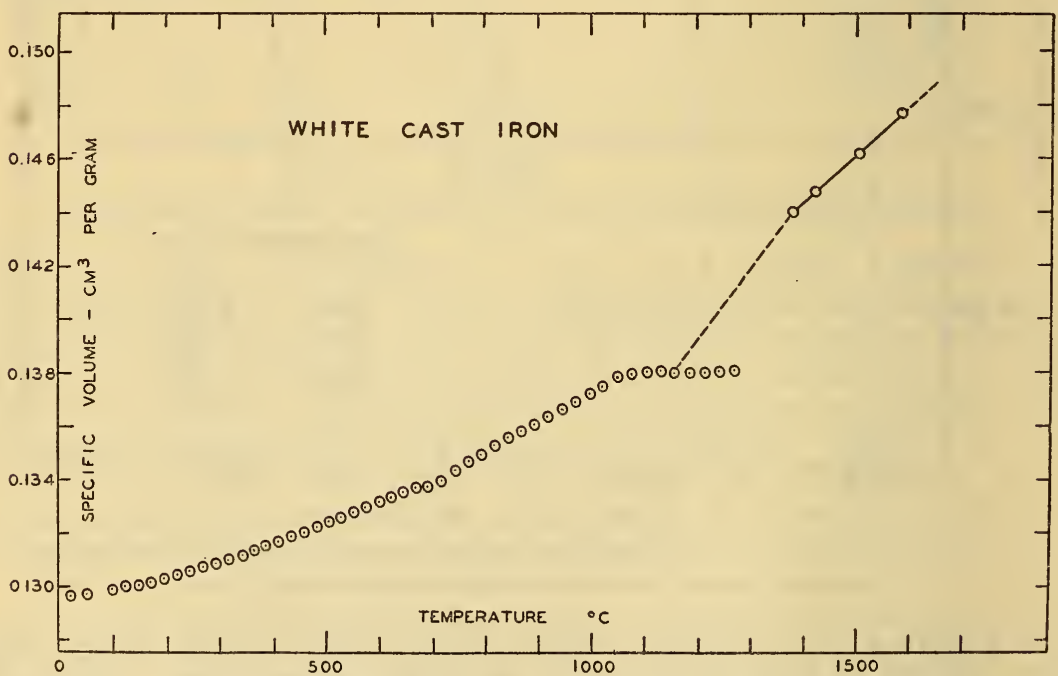

FIGURE 9.-Complete specific volume-temperature curve typical of white cast iron

Two factors may be suggested as quite probably contributing to the differences between Honda's data and the results of the present work. 
1. In the present study, the volume change during solidification has been defined ${ }^{18}$ as the change in volume in passing from the liquid state at the beginning of the freezing range to the solid state at the end of the freezing range. In alloys having a freezing range, as in many cast irons, the shrinkage during solidification includes, therefore, not only shrinkage resulting from the change of state, but also the shrinkage of the liquid and of the solid metal occurring within the range of solidification. The values given by Honda for shrinkage

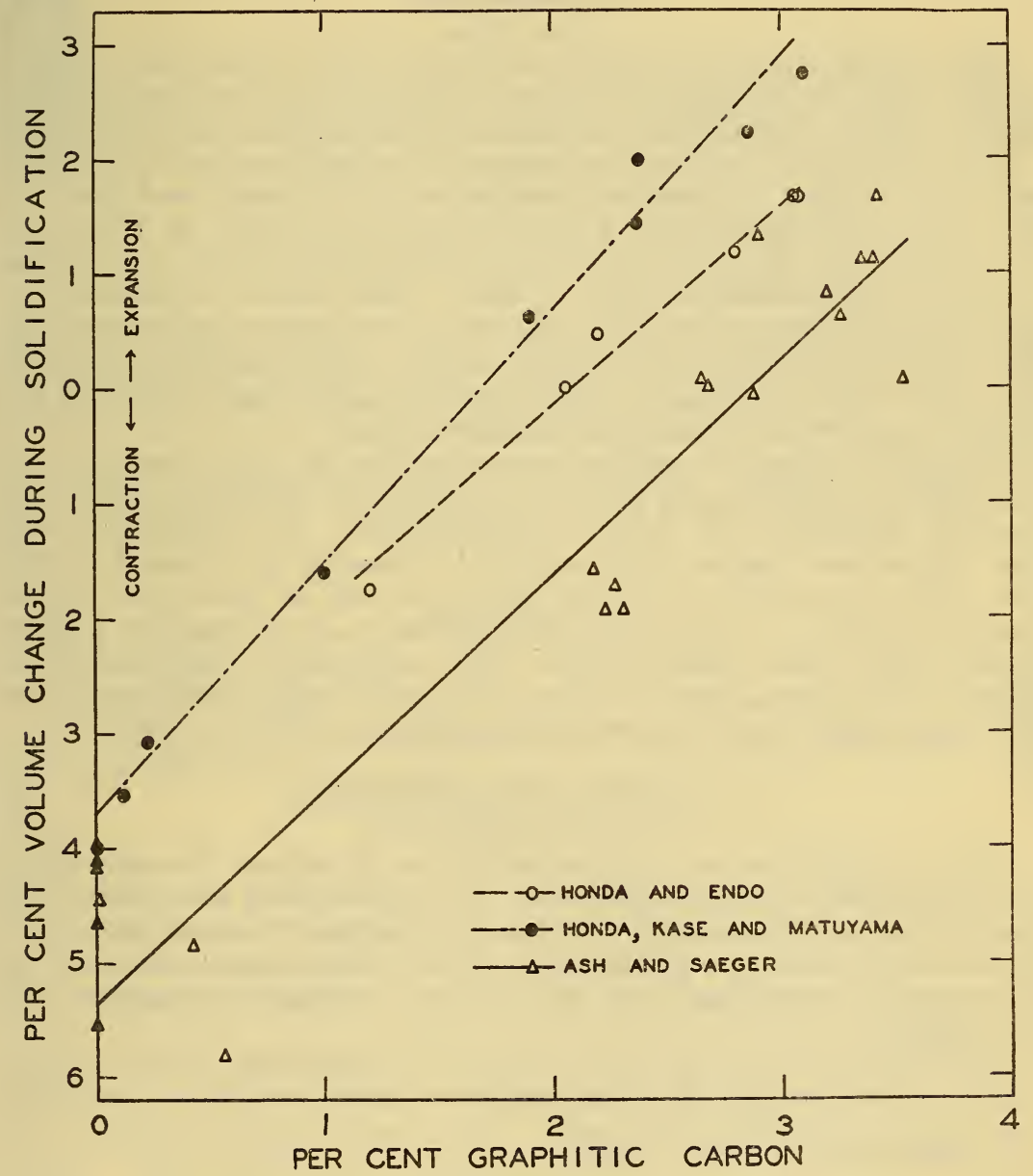

FIGURE 10.-Relation between the volume change during solidification of some cast irons and the graphitic carbon content

during solidification represent only the volume change resulting from the change of state and should be expected, therefore, to be less than the values obtained in the present work.

2. In a previous publication ${ }^{18}$ it has been pointed out that volume changes during solidification may not be measured accurately by the thermobalance owing to the very great probability of the formation of internal shrinkage cavities in the specimen during the change of 
state. Internal voids, whether localized in a pipe or distributed throughout the metal result in values for the shrinkage during solidification which are less than the correct values.

Both of these factors, therefore, the difference in definition of solidification shrinkage, and the liability of the thermobalance method to errors caused by porosity-would tend to make Honda's shrinkage values less than those of the present work.

\section{SUMMMARY}

The volume changes occurring in eight types of cast irons during cooling from the liquid state to room temperature are given in this paper. The irons varied in composition from gray iron to white iron.

The coefficient of volume shrinkage in the liquid state for the irons over the range of temperature studied was 0.011 per cent per ${ }^{\circ} \mathrm{C}$. The volume change during solidification varied from an expansion of 1.65 per cent in a gray iron to a contraction of 5.85 per cent in a low-carbon, low-silicon type of iron. The linear contraction of the sand-cast bars varied inversely with the silicon and carbon content and also with the cross-sectional area. The lowest linear shrinkage value measured was 0.67 per cent $\left(1 \frac{11 / 2}{2}\right.$-inch square bar) and the highest was 2.08 per cent $3 / 4$-inch square bar).

In both heating and cooling curves and in the sand-cast contraction bars, a pronounced effect was observed at about $1,070^{\circ} \mathrm{C}$., possibly indicative of some transformation. An expansion was observed at this temperature during the freezing of all melts of cast iron. This expansion, however, was not due to decomposition of cementite alone, for white-iron bars, having no free graphite present showed this same phenomenon. This expansion may have been caused by the separation of dissolved gases during solidification as has been pointed out by previous investigators.

\section{ACKNOWLEDGMENTS}

This investigation was sponsored by the American Foundrymen's Association from 1929 to 1931 and the authors wish to express their appreciation to the members of the gray cast-iron committee of the above association, and particularly to J. T. MacKenzie, chairman of the research committee, for his aid and counsel throughout this investigation.

Much credit is due L. D. Jones, A. I. Krynitsky, C. B. Riecks, C. E. Jackson, and H. B. Gardner, for valuable assistance rendered.

Washington, March 2, 1932. 